\title{
What the Signs Say: Language, Gentrification, and Place-Making in Brooklyn
}

\section{Madison Metsker-Galarza}

\author{
Doctoral Student \\ Texas A\&M University \\ Specializing in public engagement, \\ communication, and town and \\ gown relationships
}

m-metsker-galarza@tamu.edu

Shonna Trinch and Edward Snajdr decipher signage in a way that will prevent you from looking at a sign in the same manner again. Their research is built on a series of site visits, observations, and ethnographic interviews and they posit that signage plays an important role in gentrification. As they explain it, signs effect public space; well designed and interesting signs are important attributes of placemaking, often part of a strategy for cities to reclaim their appeal.

Trinch and Snajdr note that the "meaning of public space, even on the seemingly smallish scale of a storefront sign, can actually play a significant role in the contemporary contest over public space" (p. 3). They support this claim through rich imagery and case studies. The latter allows the reader to understand signage's role within in a community and provides examples of what can go wrong when a sign contains language and symbology that is inconsiderate and offensive to the community where the business resides.

The research is set in Brooklyn, a rapidly changing and well-documented New York City borough. Brooklyn, once a place that people would simply pass through, has become a destination location for "upper-middle-class home buyers, younger hipster renters, Manhattanites looking for new and interesting things, and tourists" (p. 18). As clearly stated by the authors, the aim of the book is to understand the role "commercial language on smallscale shops has played in marking and making gentrified space” (p. 21). The book opens with the authors describing how the site was chosen and, more interestingly, their process of collecting the data by living it through field work. Specifically, the authors conducted their field research through "interviews with residents, developers, activists, and other stakeholders, digital ethnography of websites and blogs, commentary, archival research,
Book Review /

WHAT THE SIGNS SAY

Authors:

Shonna Trinch and Edward Snajdr

Citation:

Trinch, S. \& Snajdr, E. (2020). What the Signs Say: Language, Gentrification, and Place-Making in Brooklyn. Vanderbilt University Press. 
and various types of mapping of Fort Greene and Prospect Heights" (p. 22). In an effort to triangulate their findings, the authors surveyed borough residents, community organizers, college students, and government officials.

Unlike traditional ethnographic research, where researchers can travel great distances, Trinch and Snajdr lived in their field site for fifteen years which, "created a situation in which we are always working, collecting data, talking to people, confirming our ideas of what is happening, and having our ideas challenged by new data from the ever-evolving human happenings and sense-making that is constantly taking place around us" (p. 24). The authors, as ethnographers and language analysts, understand the impact their residency has on the neighborhood and their research. The authors recognize they "fit the common intersectional profile of a gentrifier." While they are proud of and celebrate their heritage, they acknowledge their cultural background "does not orient toward any of the well-defined ethnic communities in Brooklyn" (p. 26). In effect, they remain somewhat outside of and detached from the neighborhood, giving them the ability to dissect and engage with both groups of Brooklyn residents - the gentrifying and the gentrified. Through this lens, the authors describe the complexity of the gentrification process and the role language has in creating a landscape that makes a community more desirable.

The book builds on each chapter by first understanding what makes Brooklyn a distinctive place. The first chapter includes texts and pictures, which highlight differences between the "non-corporate and local store fronts in Brooklyn's retail landscape," thereby allowing the reader to better comprehend the neighborhood's spatial contexts (p. 29). The authors introduce the idea of textual density, referring to text rich signs and signs with large font size. In their introductory analysis, the authors include signs that incorporate non-English languages. All of these examples provide a landscape that allows the reader to understand the visual diversity that exists in Brooklyn. Furthermore, this chapter introduces readers to the rules and norms of sign makers and explains the difference between old and new signage.

The authors refer to "capitalism without distinction" throughout the book, defined as "tolerance and inclusivity despite differences in people's identities, bank accounts, educational levels, and religious beliefs," (p. 60). This concept does not necessarily point to what the business sells, but rather to the clientele it attracts. This is important because often, especially in the case of new signage, what is on the sign can be different than what is behind it. New signage can be characterized by brevity, requiring the consumer to investigate what the store sells by either walking in or looking online beforehand. No matter the method, vague illusions on signage can cause the consumer to research the business, become informed, and potentially share that with their peer group. In a changing neighborhood, these new stores may not be "for" current residents. Connecting back to their primary thesis of signs and gentrification, capitalism without distinction highlights and compounds the "complicated and contentious relationships among different ethnic and racial groups who share and vie for control of a 
Brooklyn neighborhood's urban space" (p. 61). As signage advertises a business, it may also advertise a burgeoning trend toward gentrification.

The second chapter dives into modern and historic sign practices and types and analyzes the significance of signage in space and its role in the community. Signage has both positive and negative effects on the communities where these small commercial spaces are located. Trinch and Snajdr note,

The language of some shop signs functions in not so obvious ways to make distinctive places for the benefit and use of one (more or less) homogeneous group while in turn serving to gate, to close off, or perhaps even to offend other groups. These processes, we argue, are not so explicitly apparent and perhaps not intentional, yet they conspire with cultural notions of choice and other neoliberal logics to make gentrification seem organic, "normal", and inevitable." (p. 21)

The last two chapters discuss the impact of chain stores on community landscapes and how their ubiquitous branding threatens the unique visual clues of local business districts; the authors warn of placelessness that results when national chains (and their signs) replace local businesses (and their signs). While there is an ongoing debate around how governments implement signage regulation and the role signage plays in contextualizing a community, it is certain that longstanding small businesses need support from local business districts and governments to ensure that they are able to stay in areas that are gentrifying. Addressing the "high-rent blight" impacting businesses is one-way business districts and local governments can invest in their communities. Without this investment, gentrification will continue, leading to super-gentrifiers and corporate investment that threatens the sense of place.

The authors conclude with a deep dive into "intention, impact privilege, and power in people's struggle to claim space and right to define it” (p. 30). This phenomenon is not just about national businesses gentrifying historically local commercial districts, but about power between a business and the community it resides. Trinch and Snajdr provide an example of this in their discussion of Summerhill, a restaurant in rapidly gentrifying Crown Heights. As they describe it, the business owner, a former corporate tax attorney, constructed a narrative about "preserving" bullet holes in original interior walls for aesthetic purposes - to create a "visually engaging experience"-and to attract business (p. 186). The community organized to communicate their dissatisfaction with the marketing strategy, after a press release by the business owner and several published articles which focused on the inconsiderate irony of this self-mythologizing boozy sandwich shop selling " $\$ 12$ cocktails" and with "cheekily wall-papered bathrooms," (p. 185). The owner was clearly out of touch with the community's legitimate pain and feelings associated with suffering and loss brought on by foregrounding fake bullet holes. This is a prime example of a disconnected marketing gimmick introduced by a white business owner that wholly fails to recognize the historic trauma of urban communities of color. While the community seemingly preferred supporting Brooklyn-based busi- 
nesses, contempt continued to grow due to the lack of sincerity, awareness, and humility for Summerhill; ultimately contributing to the restaurant's downfall.

What the Signs Say is a narrative meant to help readers understand the role signs and visual cues have in creating space. Story driven and image laden, this work is appropriate for an academic audience, including students and researchers who have an interest in visual communications across a variety of disciplines. The book challenges readers to think intentionally about how signs and their texts, can create a sense of place. As business owners think through how they want to appeal to their primary consumer base, they must consider their environment and how certain words, art, or visuals may be perceived by everyone. Communities serve diverse populations, which include residents and tourists, and business owners' connection to the place they inhabit and their intentionality will determine their failure or success.

While the book presents case studies of how unwelcoming space impacts the surrounding community, it lacks guidance for businesses as to how they can develop signage that creates universally welcoming messaging. However, neighborhood groups, business districts, and local governments can learn how placelessness displaces small business and residents. Furthermore, while the book provides examples of how corporate investment can lead to placelessness, it would have been beneficial to learn more about investment strategies being implemented across Brooklyn to retain small business that are struggling with high-rent blight. Overall, this book allows the reader to critically engage with the role of language in signage, and whether an expert or not, this book leaves the reader thinking about signage in a critical way and challenges one to ask, "what does the sign say?" 